\title{
The Challenges of Regional Integration for Development in Africa: Problems and Prospects
}

\author{
Lanre Olu-Adeyemi and Bonnie Ayodele* \\ Department of Political Science \& Public Administration, Adekunle Ajasin University, \\ Akungba Akoko, Ondo State, Nigeria \\ E-mail: ecoob@yahoo.com \\ *Department of Political Science University of Ado Ekiti, Nigeria \\ Telephone 08028301895, E-mail: bonnieayodele@yahoo.com
}

KEYWORDS Regional integration; development; NEPAD

\begin{abstract}
Greater African integration has long been a cherished but elusive Greater African integration has long been a cherished but elusive goal. Political leaders at official conferences and formal summits have long promoted the idea, although with only limited results on the ground. There is a renewed impetus to establish closer economic and political ties among the continent's numerous countries, based on a heightened appreciation of the need for regional integration and a clearer understanding of the past failures. Political liberation and de-colonisation was the rallying ideology upon which economic integration and unity, found eloquent articulation in the 1960's. With the independence of several African States and the subsequent establishment of a plethora of integrative mechanisms, all the PanAfrican conferences were particularly unequivocal in their advocacy of freeing Africa in an all-round sense with an urge for economic cooperation as the basis of economic and political transformation. These efforts culminated to the formation of the Organization of African Unity (OAU) in 1963. Nevertheless, Africa has no positive integrative story to tell after several years of the OAU especially as the continent become threatened increasingly by its failure to cope with the challenges of development and globalisation. Thus, the current integrative reforms in the continental body constitute a response to the emerging global order. A conscious effort to expand economic and political space as well as the needed instrument to strengthen integration in Africa. This paper therefore, examines the current African integration efforts in the age of globalisation in a bid to show the current development and future challenges.
\end{abstract}

\section{INTRODUCTION}

At the dawn of independence, it was obvious that Africa's development lies in the unity of her people. Indeed, it was the quest for unity that fired African nationalism and led to panAfricanism as a guiding ideology upon which the battle for de-colonisation was fought with vigour, strength and determination. These struggles led to complete dismantling of apartheid in South Africa followed with political independence. African sovereign states have always subscribed to the principles of continental cooperation and integration. This they have demonstrated with increased determination and vociferous public declarations on the issue of regional cooperation and integration by firstly establishing Organisation of African Unity OAU even before the subject gained currency in the global development agenda and discourse.

The eventual establishment of the Organisation of African Unity (OAU) in 1963 reflects the determination and resolve of African peoples to accomplish concrete continental unity. Though ideological divisions inherited brought about as a result of different colonial political experiences among the newly independent states and nationalistic devotion of each independent states to the process of nation building and institutional development affected the strong realisation of the dream of the OAU. By the 1980s the challenge of addressing the issue of continental socioeconomic transformation was becoming more urgent. This was reinforced by the economic decline experienced from the late 1970s, the realization of the non-viability of externally dependent strategies of development and the imperative of integration

\section{BACKGROUND TO THE ISSUES}

Salim Ahmed Salim (2000) opined that "Africa have come to realise that the economic power of nations has become by far the most dominant factor in the relevance and importance of countries in the emerging global order. This is 
why even the major world powers are continuously striving to widen and strengthen the base of their economic strength, through a conscious effort to expand their economic space and market size. In the case of Africa, a continent which has been marginalized for too long a time in the world economy, integration is no longer a matter of convenience, but an indispensable strategy for survival and development".

The pace of globalisation, coupled with the sweeping wave of economic liberalisation, and with the imbalances in the distribution of the benefits in favor of the strong economies, has increased the urgency for African countries to join hands to expand, fortify, solidify and integrate their economic space, to serve as a platform for take off and effective integration into the global economy. Regional integration therefore at the very least constitutes Africa's response to globalisation, and an instrument to reverse the trend towards the marginalisation of the Continent. It cannot be disputed that some advances were made in the quest to foster closer integration in the continent through the structures of the OAU and sundry ad hoc efforts. However, the obstacles confronting African endeavor were quite immense. Africa was being threatened increasingly into marginalisation by its failure to cope with the demands of globalisation.

While even stronger economies, with their advanced technological base, were finding it necessary to consolidate their level of economic integration as a means of gaining from the opportunities of this historic phenomenon. The people of Africa were confronted with multiple setbacks of incessant conflicts, political instability, and the HIV-AIDS pandemic among other things. Efforts by individual States to resolve these numerous issues are often quashed by gargantuan external debt crisis. Thus, Africa came to realise that the magnitude of the external and internal challenges could be handled only by consolidating continental unity and that the status quo and the nascent structures of integration could not sustain the impending threat. This African response is best studied in the light of the reforms made to the existing integrative organ, that is, the OAU as well as the New Partnership for Africa's Development (NEPAD) aimed at bailing Africa from its present despondency.

\section{THE THEORETICAL ANALYSIS OF REGIONAL INTEGRATION}

Generally, regional integration can be political, economic, social or cultural. According to Haas (1971), regional integration is a process of combining separate economies into larger political communities. To the extent that political and economic forces are inextricably intertwined, any discussion of integration must encompass both economic and political variables. Also, Karl Deutsch (1971) and other early theorists have noted that authentic regional integration encompasses the whole "system". Thus, in this paper, the generic reference to regional integration is employed.

Regional integration has, thus, been defined as a process of peacefully creating a larger coherent political system out of previously separate units, each of which voluntarily cedes some part of its sovereignty to a central authority and renounces the use of force for resolving conflict between members (Laffan, 1992; Daltrop, 1986; Lodge, 1994; Deutsch, 1971). In reality, regional integration is a process, in which, seemingly, participating countries inexorably seek, inter alia, economies of scale, increased commercial activities, and uninhibited factor mobility, via "institutional integration" and "policy integration," both of which refer to the growth of collective decisionmaking and the sharing of responsibility for policies (Babarinde, 1996).

Babarinde (1996) opined that there are three broad approaches to regional integration. The first school of thought claims that the best path to regional integration is to create a higher supranational authority, to which participating states surrender part of their sovereignty. This perspective, otherwise known as the Federalist Strategy, calls for a federal structure, whereby political power is legally shared between the national and the supranational levels of government. In this case, national governments will have to surrender part of their sovereignty to the newly created supranational institutions.

At the other end of the theoretical spectrum is the Functionalist Strategy. Simply put, this approach refers to a mere functional cooperation by participating countries. Conceivably, this road to regional integration does not require member states to part with an iota of their autonomy. It merely entails and encourages inter-governmental cooperation (Lodge, 1994). A third regional integration strategy is a synthesis of the two 
models discussed above. It contends that, while the Federalist approach may be avaricious by asking for too much too hurriedly, the Functionalist appears to be evasive and lackadaisical. Hence, a common ground is proposed, which is a hybrid of the aforementioned strategies. The NeoFunctionalist Strategy posits that regional integration can best be achieved via the creation of specialized administrative institutions at the trans-national level, which shall endeavor to demonstrate the relevance and worthiness of regional integration to member states. If they are successful with their modest tasks, the argument goes, the supranational entities would be accorded more competencies by member states (Lodge, 1994).

Sovereign states participates in regional integration for various reasons because, they expect tangible benefits, whether political, economic or social. Politically, a country may participate in a regional scheme in order to bolster its military prowess, augment its political stature, and deter or wade off aggression from hostile neighbors. Similarly, countries may integrate so as to achieve economies of scale, optimally allocate scarce resources, and accelerate economic growth or to increase trade. Socially, countries may also participate in regional integration for socioeconomic reasons, either to facilitate factor mobility or to stem the influx of immigrants from less affluent neighboring countries. In any case, participating in regional endeavors can plausibly increase the fortunes of the domestic economy.

Theoretically, and in practice, regional integration framework can be further discussed, on the basis of whether they entail the removal of trade barriers or the adoption of common policies. According to Brigid Laffan (1992), most-favored nation, free trade area, and customs union, which involve the elimination of trade barriers, are manifestations of "negative integration." Conversely, common markets and economic unions denote "positive integration," because they usually require institutional edification and policy coordination. It could, thus, be generalized that the more advanced the level of integration, the greater the incidence of positive integration.

\section{AFRICAN EXPERIENCE WITH REGIONAL INTEGRATION}

African regional integration was a dream of many of the continent's leaders, and gave impetus to the creation of the Organisation of African Unity (OAU) in 1963. Over the years, many other institutions were also established in Africa's different regions. But for the most part they did little to increase trade or other interactions among African countries.

- African countries, in their quest for unity, economic and social development under the structures of the OAU, have taken various initiatives and made substantial progress in many areas which paved the way for the establishment of current efforts. Notable among these efforts are:

- Lagos Plan of Action (LPA) and the Final Act of Lagos (1980): incorporating programmes and strategies for self-reliant development and cooperation among African countries.

- The African Charter on Human and People's Rights (Nairobi 1981) and the Grand Bay Declaration and Plan of Action on Human Rights.

- Africa's Priority Programme for Economic recovery (APER) in 1985: an emergency programme designed to address the development crisis of the 1980s.

- OAU Declaration on the Political and SocioEconomic Situation in Africa and the Fundamental changes taking place in the World (1990): which underscores Africa's resolve to seize the initiative, to determine its destiny and to address the challenges to peace, democracy and security.

- The Charter on Popular Participation adopted in 1990: a testimony to the renewed determination of the OAU to endeavour to place the African citizen at the center of development and decision-making.

- The Treaty establishing the African Economic Community (AEC) - 1991: commonly referred to as Abuja Treaty, it seeks to create AEC through six stages culminating in an African Common Market using the regional Economic Communities as building blocks.

- The Mechanism for Conflict Prevention, Management and Resolution (1993): a practical expression of the determination of the African Leadership to find solution to African problems.

- Cairo Agenda for Action (1995).

- African Common Position on Africa's External Debt Crisis (1997).

- The Algiers decision on Unconstitutional Changes of Government (1999) and the Lome 
Declaration on the framework for an OAU Response to Unconstitutional Changes (2000). - The 2000 solemn Declaration on the Conference on Security, Stability, Development and Cooperation: establishes the fundamental principles for the promotion of Democracy and Good Governance in the continent.

- Africa has also initiated collective action on the protection of the environment, in combating the HIV/AIDS pandemic, malaria and tuberculosis as well as a sundry other issues.

- The Constitutive Act of the African Union: adopted in 2000 at the Lome Summit

- The New Partnership for Africa's Development (NEPAD) adopted as a programme of the AU at the Lusaka Summit in 2001.

The record of regional integration in Africa so far has been a sobering one, as uncoordinated initiatives, political conflicts and low levels of intra-regional trade marked many regional groupings. A succinct discussion of the pitfalls of past integrative efforts will suffice at this junction. To start with, there was lack of full commitment in the level of commitment often manifested in the failure to incorporate agreement reached by different integration scheme in national plans. This tendency has played down the value of collective agreements or protocols arrived at to expedite trade and harmonize policies at sub-regional levels. Also, the Civil Society and especially the private sector which is the engine of economic growth have not been actively involved in the effort to advance integration by the various African states.

Abraham (2000) opined that the unnecessary dominance of the elites in the implementation process of integration withdrew grassroots support. He also argued that African leaders have also failed to explain fully to the people the reasons for their participating in integration arrangements and the advantages, which accrue to the citizens. Another difficulty is caused by the un-equal effect of primary proponents of integration now pursue a less grandiose and more practical approach. The thrust of current efforts appears not simply to enhance the continent's weight in global affairs, but also to meet the very real needs of its people. Amoako, Executive Secretary, ECA stated that "I want to see intraAfrican integration, not because we will garner some utopian share of world commerce, but first and foremost because it will improve our lives here. It will free up the time of African businesspeople to do business here. It will lower costs. It will make the African consumer's plight so much more hopeful."(Amoako, 2003).

Recent efforts also reflect a more holistic perspective. Integration cannot be achieved by relying strictly on political initiatives or focusing narrowly on economic dynamics, as had been the case with previous undertakings. "We can never hope to separate political and economic imperatives," notes Olukoshi, executive director of the Council for the Development of Social Science Research in Africa (CODESRIA, 2003).

The AU has come at an auspicious time as the perfect instrument for enhancing Continental collaboration and integration. It has a vastly expanded mandate from that of the OAU as it includes the principles contained in the Charter of the OAU, as well as the goals entrenched in the Abuja Treaty regarding social and economic development. Apart from the above, the manner in which the $\mathrm{AU}$ is configured will help Africa to harness the opportunities of globalisation, surmount its challenges and enable Africans to realise sustainable peace and development.

The African Union represents an opportunity in which positive forces for re-invigorating the historical desire for continental integration prevailed. The vision behind it radiates the desire for the promotion of accelerated socio-economic integration of the continent, which will lead to greater unity and solidarity between African countries. Regardless of the on-going construction in terms of structures, the Continent is set to enjoy the dividends of African Union if past pitfalls of integrative efforts are not repeated. As current efforts reveal,

According to Melber (2001), the AU will make it possible for the continent to take a strong and common African position in global issues. Apart from the above, the accomplishment of socioeconomic objectives; democratic and participatory governance as well as economic integration will go a long way in re-kindling hope among Africans. The AU is no doubt working in this direction, as the current efforts to settle the crisis in Sudan is an indication of the required political will that is needed in contemporary Africa.

\section{NEPAD AND THE NEW VISION FOR AFRICA}

NEPAD is a merger of the Millennium 
Partnership for Africa's Recovery Programme and the Omega Plan (OAU, 2001). It is a project of the AU aimed at tackling issues such as peace and security, good economic, political and corporate governance, and to make the continent an attractive destination for foreign investment. A NEPAD (2001) positioning document says: 'The New Partnership for Africa's Development is a pledge by African leaders, based on a common vision and a firm and shared conviction, that they have a pressing duty to eradicate poverty and to place their countries, both individually and collectively, on a path of sustainable growth and development and, at the same time, to participate actively in the world economy and body politic.'

Writing in the African National Congress (ANC) web journal, ANC Today, President Mbeki who formulated the African Renaissance concept and is a key driver of NEPAD, said: "The challenge to end the economic marginalisation of Africa, and therefore to attract the necessary resources into our continent to ensure its development, stands at the heart both of the vision of an African Renaissance and NEPAD.'(Mbeki, 2002)

The NEPAD initiative is quite timely given the African situation and its emphasis that 'the hopes of Africa's people for a better life lie in their own hands and not on the magnanimity of others', is helping to increase Africa's profile (Omoweh, 2003). NEPAD is rooted in good governance and democracy, which distinguishes it from previous regional development initiatives. An interesting issue however is that the feasibility of democracy in Africa depends not so much on the pronouncements of African leaders, rather, it lies more on how democracy can be used to meet the social and economic needs of the people.

\section{NIGERIA'S LEADERSHIP ROLE IN AFRICAN INTEGRATION}

The role of Nigeria is extremely important at the Continental and Global level. Nigeria has in the course of its forty - four years of independence played a consistent and supportive role in promoting the integration of African economies and the emergence of the African Union. Against this backdrop Nigeria hosted OAU Heads of State who adopted the Abuja Treaty in 1991 and established the African Economic Community. Since the implementation of the provisions of the Abuja Treaty was rather slow, the OAU Heads of State at their meeting in Sirte, Libya in September 1999 made a Declaration, which was aimed at reactivating and reengineering the African integration process. The Declaration was followed by the adoption of the Act of the African Union, which was signed by the OAU Heads of State in Lome, Togo in July 2000.

The leadership of President Obasanjo in association with Presidents Mbeki, President Wade and President Boutelfika has been significant at the Global and Continental level to ensure that all African countries come to the table of integration. Nigeria in the Fourth Republic, has established a Federal Ministry of Co-Operation and Integration in Africa to demonstrate her commitment to integration in Africa.

Nigeria's commitment and resolve to the success of current efforts is aptly revealed by the commitment of its leadership. For instance, Nigeria's President Obasanjo is Chairman of the African Union; Chairman of the Global Implementation Committee of NEPAD and is also Chairman of the Heads of State Steering Committee. This singular honor done to Nigeria coupled with the fact that NEPAD was formalized at Abuja in 2001 give some indication as to the pivotal role Nigeria is expected to play in the process and of course reflects the country's record of engagement on the continent (NEPAD, 2003).

Nigeria is also Chairman of the Steering Committee on Economic and Corporate Governance and the Committee on Capital Flows. Nigeria is in fact also Vice-Chairman of the Committee on Infrastructure and as such will be involved in the development of the detailed regional and trans-continental infrastructure priority projects, which it is hoped will transform Africa (ibid).

Nigeria realized early the central role of democracy to these reforms and has taken up the responsibility to monitor democratic issues in Africa. Till date, Nigeria has deployed structures to monitor elections across Africa.

\section{THE ROAD AHEAD}

Africa has re-started on good grounds by drawing extensively from the experiences of the European Union in re-drawing the strategies of Continental integration. This is germane because a way to encourage integration is to learn from the experience of other regions, which have 
achieved a measure of success. There is also the increasing need to strengthen bilateral links, which in turn provide a basis for multi-lateral cooperation. Also, Africa needs to promote and expand trade as well as the movement of capital, peoples, goods and services. This is bound to assist the member states to mutually benefit.

Joint efforts should also be made to improve the precondition for enhanced integration through initiatives aimed at infrastructures, which are unaffordable for the small states. Together with this, measures should be taken to remove tariff bulwarks and encourage division of labour, quicken specialisation in production and stimulate economies of scale.

There is need to develop conflict prevention mechanisms through a sub-regional program of education in order to mediate actively in conflict situations. The smaller integrative blocs such as ECOWAS, SADC etc. in turn should create mechanisms of preventing conflicts and promoting a culture of tolerance and compromise. One reason for this is that integration is best developed in an atmosphere of trust and confidence among nations and their populations. Above all, there is need to establish a formidable research institute to help in assessing the programmes of current integration as well as the level of accomplishment of continental efforts. This is necessary to improve the economic and political environment for technological innovation and development. The integration of Africa may be a complex process, but the stakes are high, and will ultimately determine the Continent's political and economic future.

\section{REFERENCES}

Abraham, K. 2000. "The Challenges and Prospects of Pan-African Economic Integration.” Paper presrnted at the conference on Economic Integration and Transboundary Resources Organised by the Ethiopian International Institute for Peace and Development (EIIPD), June, Addis Ababa

Amoako, K. 2003. (Amoako K.Y is the Executive Secretary of the Economic Commission for Africa).

Babarinde, O.A. 1996. Analyzing the Proposed African Economic Community: Lessons from the Experience of the European Union, Prepared for the Third ECSA-World Conference on The European Union in a Changing World, Sponsored by the European Commission, D-G X, Brussels, Belgium, 19-20 September, 1996.

CODESRIA. 2003. Africa and the Challenges of Regional Development. Dakar, Senegal

Daltrop, A. 1986. Political Realities: Politics and the European Community. London: Longman.

Deutsch, K. 1971. The Analysis of International Relations. Englewood Cliffs, NJ: Prentice-Hall.

Haas, E. 1971. Beyond the Nation-States: Functionalism and International Organization. Stanford, California: Stanford University Press.

Laffan, B. 1992. Integration and Co-operation in Europe. London: Routledge.

Lodge, J. 1994. "Transparency and Democratic Legitimacy." Journal of Common Market Studies, 32: 4569

Melber, H. 2001. The New African Initiative and the African Union: A Preliminary Assessment and Documentation, Uppsala: Nordiska, No. 25.

NEPAD. 2001. The New Partnership for African Development Document. www,nepad.org

NEPAD. 2003. The New Partnership for African Development Document. www,nepad.org

OAU. 2001. African Union and Continental Stability Document www.allafrican.com

Omoweh, A.D. 2003. "Re-thinking Integration in Africa." Journal for Diplomacy and Foreign Relations, 13(1): 34-42 